\title{
Isolasi dan Karakterisasi Kitosan dari Cangkang Rajungan (Portunus pelagicus)
}

\author{
Irza Dewi Sartika ${ }^{1}$, Moch. Amin Alamsjah ${ }^{2}$ Noor Erma Nasution Sugijanto ${ }^{3 *}$ \\ ${ }^{1}$ Program Studi Bioteknologi Perikanan dan Kelautan, Universitas Airlangga, Surabaya \\ ${ }^{2}$ Fakultas Perikanan dan Kelautan, Universitas Airlangga, Surabaya \\ ${ }^{3}$ Fakultas Farmasi, Universitas Airlangga, Surabaya \\ e-mail: ${ }^{1}$ irza.dewisartika20@gmail.com, ${ }^{3 *}$ ermasugianto@yahoo.co.id,
}

\begin{abstract}
Abstrak
Rajungan (Portunus pelagicus) merupakan spesies (Crustacean),cangkangnya tidak dimanfaatkan sehingga menimbulkan limbah yang dapat mencemari lingkungan untuk itu perlu diolah menjadi bahan yang bernilai ekonomi seperti kitosan.

Penelitian ini bertujuan mengisolasi dan melakukan karakterisasi kitin dan kitosan dari cangkang Rajungan.

Hasil penelitian menunjukkan rendemen kitin diperoleh $23,9873 \pm 5,5573 \%$ kitosan dari cangkang Rajungan diperoleh 13,2724 $\pm 1,9338 \%$ dengan derajat deasetilasi 70,73 $\pm 2,9143 \%$. Hasil penelitian ini menunjukkan kitosan dapat diisolasi dari cangkang rajungan .
\end{abstract}

Kata kunci: Rajungan (Portunus pelagicus), Kitosan, Isolasi

\begin{abstract}
Portunus pelagicus is Crustacean species, the shells polluted the environment, so it can be processed to the valuable materials such as chitosan. pelagicus

The aims of the study is to isolate and characterization of the chitosan from Portunus

The results showed that the the yield obtained for extracted chitin was 23,9873 $\pm 5,5573$ $\%$, chitosan was $13.2724 \pm 1,9338 \%$ with degree of deacetylation $70.73 \pm 2,9143 \%$ from Portunus pelagicus. The result showed that chitosan can be isolated from Portunus pelagicus
\end{abstract}

Keywords: Portunus pelagicus, Chitosan, Heavy metals, $\mathrm{Cu}^{2+}$

\section{PENDAHULUAN}

Sumber daya laut yang sangat melimpah dan beragam dapat dimanfaatkan seoptimal mungkin bagi kesejahteraan manusia. Organisme laut berpotensi tinggi sebagai bahan berkhasiat. Pandangan ini cukup beralasan, karena lingkungan laut dicirikan dengan kisaran kondisi yang sangat luas dan beragam, mulai dari suhu, tekanan, nutrien hingga intensitas cahaya matahari (Rumengan, 2014). Laut merupakan sumber bahan alami dengan organisme invertebrata dari kelompok Molusca sp, Coelenterata sp, Annelida sp, Nematoda sp dapat dimanfaatkan manusia sebagai sumber protein maupun bahan berkhasiat yang lain. Salah satu sumber protein hewani yang berasal dari laut adalah rajungan, proteinnya cukup lengkap, karena asam amino esensialnya tinggi, mudah dicerna tubuh, serta merupakan sumber vitamin yang larut lemak dan air. Di daging kerang darah (Anadara granosa) didapatkan vitamin larut lemak berupa A, D, E, dan K, sedangkan vitamin larut air terutama B-kompleks seperti B-1, B-2, B-6 (piridoxin), B-12, dan niasin.

Rajungan hidup pada semua tipe perairan yaitu air tawar, estuari dan laut. terdistribusi dari daerah intertidal, laut dangkal dan ada yang mendiami perairan laut dalam (Nurdin, 2009).

Di Indonesia cangkang rajungan masih menjadi limbah yang dibuang dan menimbulkan masalah bagi lingkungan. Data statistik menunjukkan negara yang memiliki industri pengolahan hasil laut menghasilkan sekitar 56.200 ton limbah pertahun (Departemen Kelautan dan 
Perikanan, 2000). Limbah cangkang ini sangat berpotensi menjadi produk yang lebih bernilai, yaitu kitin dan kitosan dibandingkan pemanfaatan yang selama ini hanya sebagai bahan penimbun tanah dan asesoris serta hiasan dinding.

Salah satu bahan berkhasiat dari laut adalah kitin dan kitosan. Sumber utama kitin dan kitosan ialah cangkang Crustaceae sp, yaitu udang, lobster, kepiting, kerang-kerangan, rajungan serta hewan yang bercangkang lainnya, terutama yang berasal dari laut (Hawab, 2005). Pasar dunia untuk produk turunan kitin menunjukkan bahwa oligomer kitosan adalah produk yang termahal, yaitu senilai \$ USD 60.000/ton.

Penggunaan kitosan pernah dilaporkan antara lain oleh Dedeh et al., (2012) dan Zury et al., (2014) kitosan sebagai carrier untuk elektroda. Moftah et al., (2013), Akhmad dan Motomizu (2013), Hanandayu et al., (2013), dan Darjito et al., (2014) menggunakan kitosan dan kitosan termodifikasi sebagai adsorben logam berat. Dalam penelitian penurunan kadar logam berat yang dilakukan Rahayu (2007) menyatakan bahwa kitosan dari limbah cangkang rajungan dapat menjadi adsorben pada logam berat merkuri. Hasil penelitian menunjukkan bahwa semakin tinggi $\mathrm{pH}$ adsorpsi semakin besar penurunan jumlah ion merkuri (\%). pH yang paling optimal adalah pH 5.

Cangkang rajungan juga mengandung kitin dan kitosan yang merupakan senyawa biopolimer paling banyak kedua ditemukan di alam setelah selulosa, atau biopolimer yang mengandung nitrogen $(\mathrm{N})$ terbanyak yang ada di alam. Adanya $\mathrm{N}$ yang tinggi dalam polimer inilah yang membuat kitin dan kitosan sangat diminati industri. Adanya atom nitrogen dan oksigen pada kitosan dapat membentuk kompleks dengan logam berat. Kitosan memiliki sifat-sifat yang dapat digunakan antara lain untuk pengolahan limbah cair terutama meminimalisasi logam-logam berat, mengkoagulasi minyak/lemak, serta mengurangi kekeruhan atau sebagai penstabil minyak, rasa dan lemak dalam produksi industri pangan (Rismana, 2004). Secara definitif, kitosan merupakan kitin yang telah mengalami deasetilasi dan menyisakan gugus asetil tidak lebih dari 40-45\% (Lina et aI., 2001). Namun demikian, di industri lazim digunakan batasan deasetilasi hingga $70 \%$. Tingkat deasetilasi ini penting, sebab merupakan parameter yang mempengaruhi karakteristik seperti kelarutan, reaktivitas kimia, dan biodegradabilitas kitosan yang diperoleh (Lamarque et al., 2005). Tingkat deasetilasi dapat berkisar antara 30 hingga $95 \%$ tergantung pada sumber bahan baku dan prosedur dalam proses pengolahannya (Martino et al., 2005).

Mengolah cangkang menjadi kitosan dapat dilakukan melalui tiga proses yaitu deproteinasi yang bertujuan untuk menghilangkan sisa protein dari daging kerang, demineralisasi untuk mengurangi kadar mineral (CaCO3) dengan menggunakan asam konsentrasi rendah untuk mendapatkan kitin. Selanjutnya deasetilasi untuk menghilangkan gugus asetil dari kitin melalui pemanasan dalam larutan alkali kuat dengan konsentrasi tinggi (Yunizal et al., 2001).

Berkaitan dengan hal tersebut diatas pada penelitian ini dikaji limbah cangkang Rajungan (Portunus pelagis) yang ada di Indonesia khususnya di Pantai Kenjeran agar dapat dimanfaatkan sebagai sumber kitin dan kitosan. Sumber untuk isolasi kitin dan kitosan ini diutamakan dari bahan dengan nilai ekonomi rendah disamping mengolah limbah cangkang menjadi produk kitosan yang bernilai jual.

Perairan Pantai Kenjeran ditengarai terkontaminasi oleh logam berat (Sudarmaji et al., 2004) untuk itu perlu dicari solusi bagaimana mengatasinya. Kitosan dilaporkan dapat menurunkan kadar logam berat (Rahayu, 2007) untuk itu kitosan yang dihasilkan dari Rajungan diuji kemampuannya dalam menurunkan atau mengadsorbsi larutan logam berat yang dalam hal ini sebagai model digunakan $\mathrm{Cu}^{2+}$.

\section{TINJAUAN PUSTAKA}

\subsection{Rajungan (Portunus pelagis)}

Taksonomi Rajungan menurut Saanin (1984) sebagai berikut :

$\begin{array}{ll}\text { Filum } & : \text { Arthropoda } \\ \text { Kelas } & \text { : Crustacea } \\ \text { Sub kelas } & \text { : Malacostraca } \\ \text { Ordo } & \text { : Eucaridae } \\ \text { Sub ordo } & : \text { Decapoda } \\ \text { Famili } & : \text { Portunidae } \\ \text { Genus } & : \text { Portunus } \\ \text { Spesies } & : \text { Portunus pelagis }\end{array}$


Morfologi Rajungan dapat dilihat pada Gambar 1. Suku Portunidae mempunyai karapas atau cangkang lebar sekali, lebarnya dapat mencapai $2 / 3$ kali panjangnya. Dahi bergigi empat buah, gigi sebelah luar lebih besar dan lebih menonjol, gigi ini lebih rendah dan lebih membulat pada individu yang belum dewasa. Capit memanjang, kokoh, mempunyai duri sebanyak 9 , 6,5 , atau 4 pada sisi depan.

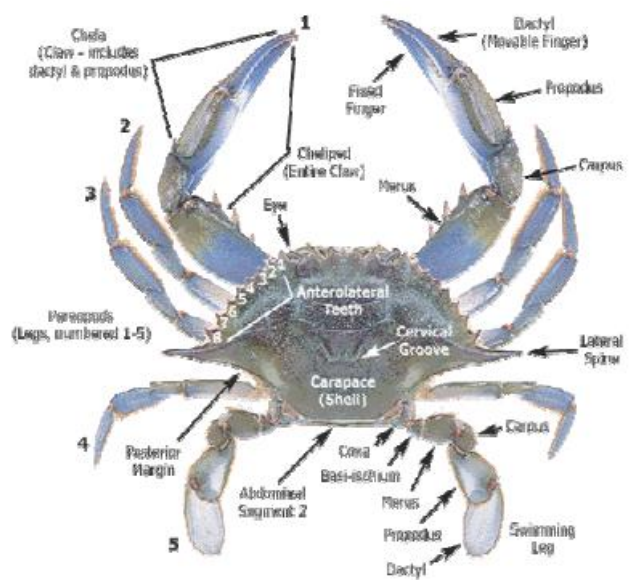

Gambar 1. Deskripsi Rajungan (Portunus pelagis)

Menurut Prianto (2007), walaupun rajungan mempunyai bentuk dan ukuran yang beragam tetapi seluruhnya mempunyai kesamaan pada bentuk tubuh. Chelipeds terletak di depan kaki pertama dan setiap jenis memiliki struktur chelipeds yang berbeda-beda. Chelipeds dapat digunakan untuk memegang dan membawa makanan, menggali, membuka kulit kerang dan juga sebagai senjata dalam menghadapi musuh. Carapace merupakan kulit yang keras atau dengan istilah lain exoskeleton (kulit luar) berfungsi untuk melindungi organ bagian kepala, badan dan insang.

Mulut rajungan terbuka dan terletak pada bagian bawah tubuh. Beberapa bagian yang terdapat di sekitar mulut berfungsi memegang makanan dan juga memompakan air dari mulut ke insang. Rajungan memiliki rangka luar yang keras sehingga mulutnya tidak dapat dibuka lebar.

Menurut Juwana dan Kasijan (2000), rajungan dan kepiting sebenarnya satu famili atau satu suku. Karapasnya mempunyai pinggiran samping depan yang bergerigi dan jumlah giginya sembilan buah. Perutnya atau yang biasa disebut abdomen terlipat ke depan di bawah karapas. Abdomen jantan sempit dan meruncing ke depan.

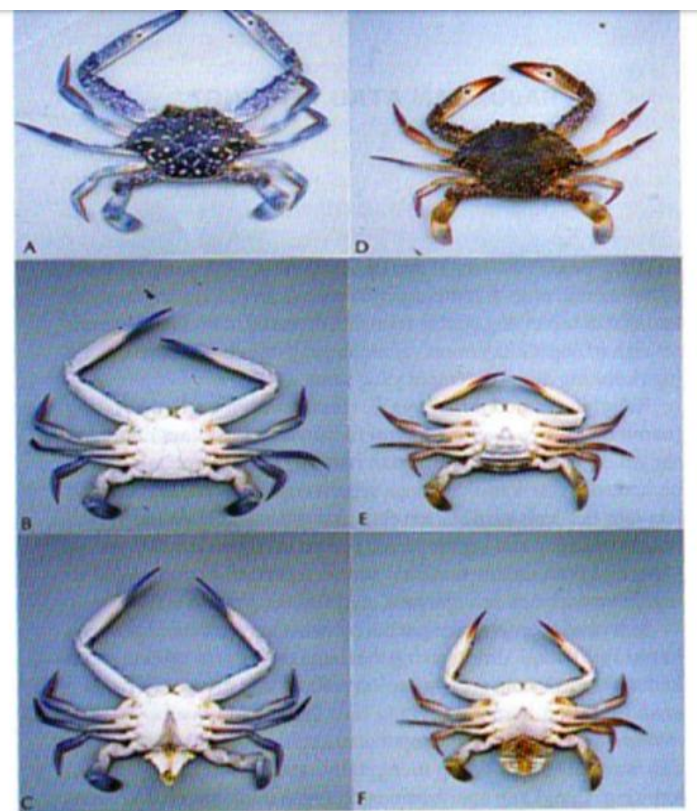

Gambar 2. Morfologi Rajungan Jantan dan Betina (Juwana dan Kasijan, 2000)

Keterangan :

A = Rajungan jantan dilihat dari atas

$\mathrm{B}=$ Rajungan jantan dilihat dari bawah

$\mathrm{C}=$ Rajungan jantan dengan abdomen dibuka

$\mathrm{D}=$ Rajungan betina dilihat dari atas

$\mathrm{E}=$ Rajungan betina dilihat dari bawah

$\mathrm{F}=$ Rajungan betina dengan embelan (pleopod)

Abdomen betina melebar dan membulat penuh dengan embelan, gunanya untuk menyimpan telur.

Bagian tubuh kepiting juga dilengkapi bulu dan rambut sebagai indera penerima. Bulu-bulu terdapat hampir di seluruh tubuh tetapi sebagian besar bergerombol pada kaki jalan. Kepiting menemukan makanannya menggunakan rangsangan bahan kimia yang dihasilkan oleh organ tubuh. Antena memiliki indera penciuman yang mampu merangsang kepiting untuk mencari makan. Ketika alat pendeteksi pada kaki melakukan kontak langsung dengan makanan, chelipeds dengan cepat menjepit makanan tersebut dan langsung dimasukkan ke dalam mulut. Mulut kepiting juga memiliki alat penerima sinyal yang sangat sensitif untuk mendeteksi bahan-bahan kimia. Kepiting mengandalkan kombinasi organ perasa untuk menemukan makanan, pasangan dan menyelamatkan diri dari predator (Prianto, 2007).

Kepiting termasuk dalam beberapa suku (familia), Portunidae dan seksi (sectio) Brachyura. Rajungan (Portunus pelagis) sering berganti kulit 
secara teratur. Kulit kerangka tubuhnya terbuat dari bahan berkapur dan karenanya tak dapat terus tumbuh. Jika ia akan tumbuh lebih besar maka kulitnya akan retak pecah dan dari situ akan keluar individu yang lebih besar dengan kulit yang masih lunak. Rajungan yang baru berganti kulit, tubuhnya masih sangat lunak. Masa selama bertubuh lunak ini merupakan masa yang sangat rawan dalam kehidupannya, karena pertahanannyapun sangat lemah. (Juwana, 2000)

\subsection{Kitosan}

Kitosan merupakan senyawa turunan kitin, memiliki struktur (1,4)-2-Amino-2-Deoksi- $\beta$-DGlukosa. Sumber kitosan yang sangat potensial adalah rangka Crustaceae (Muzzarelli, 1977). Kitosan merupakan polimer alami dengan struktur molekul yang menyerupai selulosa bedanya terletak pada gugus rantai C-2 dimana gugus hidroksi $(\mathrm{OH})$ pada $\mathrm{C}-2$ digantikan oleh amina (NH2) (Hardjito, 2006).
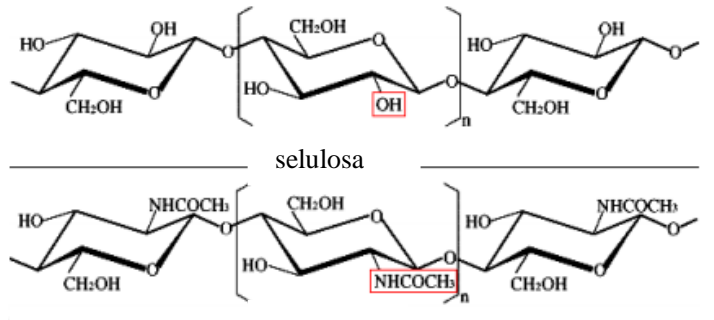

kitin

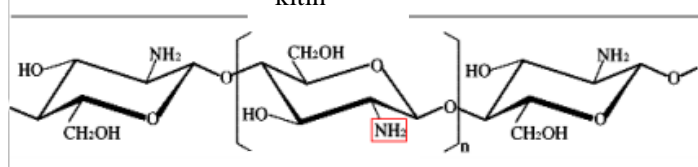

Gambar 3. Rumus sı unıuı selulosa, kitin dan kitosan

Secara struktural, kitosan merupakan polimer rantai lurus (straight-chain polymer) yang terdiri dari D-glukosamin dan N-asetil-D-glukosamin. Kitosan mempunyai rumus umum $(\mathrm{C} 6 \mathrm{H} 11 \mathrm{NO} 4) \mathrm{n}$ atau disebut sebagai poli(2-amino-2-deoksi- $\beta$-Dglukosa) (Fernandez-Kim, 2004). Kitosan memiliki pKa 6,5 sehingga kitosan dapat larut dalam sebagian besar larutan organik yang bersifat asam dan memiliki $\mathrm{pH}$ kurang dari 6,5 termasuk format, asetat, tartarat, dan asam sitrat (LeHoux dan Grondin, 1993; Peniston and Johnson, 1980).

Kandungan kitin dari beberapa sumber diantaranya di tabelkan pada Tabel 1:
Tabel 1. Beberapa Sumber Organisme Penghasil

Kitin dan Kitosan.

Sumber : Shirosi, (1981) dalam Knorr, (1984)

\begin{tabular}{|c|c|c|}
\hline No & Jenis Organisme & $\begin{array}{c}\text { Kandungan } \\
\text { Kitin }(\%)\end{array}$ \\
\hline 1 & $\begin{array}{ll}\text { Crustanceae } \\
-\quad \text { Kepiting } \\
-\quad \text { Lobster:(Nephops, } \\
\quad \text { dan Homarus) }\end{array}$ & $\begin{array}{c}72,1^{\mathrm{a}} \\
69,8^{\mathrm{a}} \\
(60,8-77,0)^{\mathrm{a}}\end{array}$ \\
\hline 2 & $\begin{array}{l}\text { Serangga } \\
-\quad \text { Kecoa } \\
-\quad \text { Lebah } \\
-\quad \text { Ulat sutra }\end{array}$ & $\begin{array}{c}18,4^{\mathrm{a}} \\
(27-35)^{\mathrm{a}} \\
44,2^{\mathrm{a}}\end{array}$ \\
\hline 3 & $\begin{array}{l}\text { Molusca } \\
-\quad \text { Kulit resmis } \\
-\quad \text { Kulit tiram }\end{array}$ & $\begin{array}{l}6,1 \\
3,6\end{array}$ \\
\hline 4 & $\begin{array}{ll}\text { Jamur } \\
- & \text { Aspergillus niger } \\
- & \text { Penicillium } \\
& \text { Chrysogenium } \\
- & \text { Saccharomyceae } \\
& \text { cereviciae } \\
- & \text { Lactarius vellerius } \\
& \text { (Mushroom) }\end{array}$ & $\begin{array}{l}42,0^{\mathrm{b}} \\
20,1^{\mathrm{b}} \\
2,9^{\mathrm{b}} \\
19,0^{\mathrm{b}}\end{array}$ \\
\hline
\end{tabular}

Keterangan:

$\mathrm{a}=$ Berat organik dari kutikula

$\mathrm{b}=$ Berat kering dari dinding sel

Kitosan tidak larut dalam asam fospat dan asam sulfat. Kelarutan kitosan, kemampuannya terbiodegradasi, reaktivitas, dan adsorbsi oleh banyak substrat tergantung dari jumlah gugus amino yang terprotonasi dalam rantai polimer, selain dari perbandingan jumlah unit D-glukosamin yang terasetilasi dan tidak terasetilasi. Gugus amina (pKa 6,2-7,0) akan terprotonasi dalam asam dengan pKa yang lebih rendah dari 6,2, sehingga kitosan dapat terlarut (Guibal, 2004; Kubota, 2000; Kurita, 2006; Anthonsen dan Smidsroed, 1995; Rinaudo, 2006; Sankararamakrishnan dan Sanghi, 2006). Di dalam asam, gugus amina pada kitosan akan terprotonasi menjadi ammonium kuartener ($\mathrm{NH} 3+$ ) sehingga kitosan menjadi bermuatan positif.

Kitosan dipilih sebagai polimer yang baik untuk aplikasi biomedis dan farmasetik karena sifat yang dimilikinya yaitu, kemampuannya terbiodegradasi, biokompatibel, memiliki daya antimikroba, dan tidak toksik. Kitosan ditemukan oleh C. Rouget pada tahun 1859. Dia menemukan bahwa kitin yang telah dididihkan pada larutan $\mathrm{KOH}$ juga dapat diperlakukan dengan $\mathrm{NaOH}$ panas maka akan terjadi pelepasan gugus asetil (proses 
deasetilasi) yang terikat pada atom nitrogen menjadi gugus amino bebas yang disebut dengan kitosan (Zakaria, 2002).

Kitin murni mengandung gugus asetamida (NH-COCH3), dan kitosan murni mengandung gugus amino (NH2). Perbedaan gugus ini akan mempengaruhi sifat - sifat kimia senyawa tersebut (Roberts,1992).

\subsection{Sifat-Sifat Kitosan}

Kitosan adalah padatan amorf putih yang tidak larut dalam alkali dan asam mineral kecuali pada keadaan tertentu. Keterlarutan kitosan yang paling baik ialah dalam larutan asam asetat $1 \%$, asam format $10 \%$ dan asam sitrat $10 \%$. Kitosan tidak dapat larut dalam asam piruvat, asam laktat, dan asam-asam anorganik pada $\mathrm{pH}$ tertentu, walaupun setelah dipanaskan dan diaduk dengan waktu yang agak lama. Keterlarutan kitosan dalam larutan asam format ataupun asam asetat dapat membedakan kitosan dan kitin karena kitin tidak dapat melarut dalam pelarut asam tersebut.

Kitosan bermuatan positif karena kelompok amina pada $\mathrm{pH}$ asam, yang besarannya tergantung pada tingkat deasetilasi, dan dengan demikian kitosan diklasifikasikan sebagai polielektrolit kationik, sedangkan polisakarida yang lain memberikan muatan netral ataupun anionik. (Hwang dan Shin, 2001).

\subsection{Kegunaan Kitosan}

Kitosan merupakan polimer karbohidrat termodifikasi yang diperoleh dari deasetilasi kitin serta memiliki karakteristik yang baik dan unik meliputi kemampuannya yang biodegradable, biokompatibel, bioaktif, dan non-toksik, sehingga kitosan telah banyak dipelajari dan diteliti untuk penggunaan dalam bidang bioteknologi, water treatment, pertanian, farmasi, dan industri makanan (Kumar, 2000; Rinaudo, 2006; Shahidi dkk., 1999). Adanya gugus $\mathrm{NH} 2$ pada kitosan menjadi alasan mengapa kitosan memiliki potensi yang lebih baik dibandingkan kitin pada berbagai aplikasi yang berbeda (Honarkar dan Barikani, 2009).

Pada aplikasi tertentu diperlukan bobot molekul kitosan yang spesifik. Secara umum, kitosan dengan bobot molekul yang tinggi tidak dapat terlarut dalam air. Kitosan yang terdegradasi akan memiliki bobot molekul yang lebih rendah sehingga dapat lebih mudah larut dalam air dan memiliki perbedaan signifikan dalam aktivitasnya sebagai antimikroba, antitumor, dan aktivitas pertumbuhan tanaman dibandingkan kitosan dengan bobot molekul yang lebih tinggi (Hien dkk., 2012).
Kitosan digunakan dalam berbagai industri antara lain farmasi, kesehatan, biokimia, bioteknologi, pangan, pengolahan limbah, kosmetik, agroindustri, industri tekstil, industri perkayuan, industri kertas dan industri elektronika. Aplikasi khusus berdasarkan sifat yang dipunyainya antara lain untuk pengolahan limbah cair terutama bersifat resin penukar ion untuk meminimalisasi logam-logam berat, mengkoagulasi minyak / lemak, serta mengurangi kekeruhan, penstabil minyak, rasa dan lemak dalam produksi industri pangan. (Rismana, 2004).

Tabel 2. Aplikasi Kitosan dalam berbagai Bidang: (Suhartono, 2006)

\begin{tabular}{ll}
\hline \multicolumn{1}{c}{ Bidang } & \multicolumn{1}{c}{ Penggunaan } \\
\hline Nutrisi & Suplemen nutrisi \\
& Suplemen serat laut \\
Pangan & Nutraseutikal, senyawa \\
& penyerap lemak \\
& Perisa \\
& Emulsifier \\
& Pembentuk tekstur \\
& Penjernih minuman \\
Biomedis & Mengobati luka \\
& Lensa kontak \\
& Membrane dialysis \\
& darah \\
& Antitumor \\
Kosmetik & Krim pelembab \\
& Produk perawatan \\
& rambut \\
Lingkungan & Penjernih air \\
pertanian & Mmenyimpan benih \\
& Pupuk dan fungisida \\
Lain-lain & Proses \\
& kertas pembuatan \\
& Penyerap warna pada \\
& produk cat \\
& Bahan tambahan pakan \\
\hline
\end{tabular}

Kemampuan kitosan untuk mengikat logam dengan cara mengkelat dihubungkan dengan kadar nitrogen yang tinggi pada rantai polimernya. Kitosan mempunyai satu kumpulan amino linier bagi setiap unit glukosa. Kumpulan amino ini mempunyai sepasang elektron yang dapat berkoordinasi atau membentuk ikatan-ikatan aktif dengan kation-kation logam. Unsur nitrogen pada 
Jurnal Biosains Pascasarjana Vol. 18 (2016) pp

(C) (2016) Sekolah Pascasarjana Universitas Airlangga, Indonesia

setiap monomer kitosan dikatakan sebagai gugus yang aktif berkoordinasi dengan kation logam. (Hutahahean, 2001)
Isolasi Kitosan yang dilakukan dengan berbagai sumber bahan baku dan proses dirangkum dalam tabel berikut:

Tabel 3. Isolasi Kitosan dalam berbagai Penelitian :

\begin{tabular}{|c|c|c|c|c|c|}
\hline $\begin{array}{l}\text { Isolasi kitosan } \\
\text { dari sumber } \\
\text { nya \& } \\
\qquad \text { literature }\end{array}$ & $\begin{array}{l}\text { Bekicot } \\
\text { (Triana, 2004) }\end{array}$ & $\begin{array}{l}\text { Rajungan } \\
\text { (Portunus } \\
\text { pelagicus) } \\
\text { (Matheis, 2012) }\end{array}$ & $\begin{array}{l}\text { Rajungan } \\
\text { (Portunus } \\
\text { pelagicus) } \\
\text { (Yuliusman, } \\
2010)\end{array}$ & $\begin{array}{l}\text { Rajungan } \\
\text { (Portunus } \\
\text { pelagicus) } \\
\text { (Sukma,2014) }\end{array}$ & $\begin{array}{l}\text { Rajungan } \\
\text { (Portunus } \\
\text { pelagicus) } \\
\text { (Rahayu, } \\
2007 \text { ) }\end{array}$ \\
\hline Deproteinase & $\begin{array}{l}\mathrm{NaOH} 3,5 \% \\
10: 1(\mathrm{v} / \mathrm{b}), \\
65^{\circ} \mathrm{C}\end{array}$ & $\begin{array}{l}\mathrm{NaOH} 3,5 \% \\
1: 10(w / v) 65^{0} \mathrm{C} \\
2 \mathrm{jam}\end{array}$ & $\begin{array}{l}\mathrm{NaOH} 1 \mathrm{M} \\
\text { suhu } 70^{\circ} \mathrm{C}, 1 \\
\text { jam }\end{array}$ & $\begin{array}{l}\mathrm{NaOH} 4 \% \\
1: 10(\mathrm{~b} / \mathrm{v}) \\
\text { suhu } 100^{\circ} \mathrm{C} \\
12 \mathrm{jam}\end{array}$ & $\begin{array}{l}\mathrm{NaOH} 2,0 \mathrm{~N} \\
1: 6 \text { (b/v) suhu } \\
80^{\circ} \mathrm{C} \text { waktu } 1 \\
\text { jam }\end{array}$ \\
\hline Demineralisasi & $\begin{array}{l}\mathrm{HCl} 1 \mathrm{~N} \\
(15: 1)(\mathrm{v} / \mathrm{b}), \\
40^{\circ} \mathrm{C}, 30^{1}, \\
60^{\circ} \mathrm{C}\end{array}$ & $\begin{array}{l}\text { HCL } 1,0 \mathrm{~N} 1: 15 \\
(\mathrm{w} / \mathrm{v}) \text { waktu } \\
30^{\mathrm{I}} \text { suhu } 20- \\
25^{0} \mathrm{C} \text {, suhu } 60^{0} \\
\mathrm{C} \text { waktu } 4 \text { jam }\end{array}$ & $\begin{array}{l}\mathrm{HCl} 1 \mathrm{M} \text { suhu } \\
60^{\circ} \mathrm{C} \text {, waktu } 1 \\
\text { jam }\end{array}$ & $\begin{array}{l}\mathrm{HCl} 2 \mathrm{~N} \\
1: 4(\mathrm{~b} / \mathrm{v}) 24 \\
\text { jam padatan } \\
\text { oven suhu } \\
100^{\circ} \mathrm{C} \text { waktu } \\
24 \mathrm{jam}\end{array}$ & $\begin{array}{l}\mathrm{HCl} 1,5 \mathrm{~N} \\
1: 12(\mathrm{~b} / \mathrm{v}) \\
\text { suhu } 20-25^{\circ} \mathrm{C} \\
1 \text { jam, di } \\
\text { oven suhu } 70- \\
80^{0} \mathrm{C} \text { waktu } \\
24 \text { jam }\end{array}$ \\
\hline Depigmentasi & $\begin{array}{l}\mathrm{NaOCl} \\
0,315 \% 10: 1 \\
\text { (v/b) } 1 \mathrm{jam} \\
\text { suhu } 40^{\circ} \mathrm{C}\end{array}$ & $\begin{array}{l}\text { Aseton } \\
\mathrm{NaOCl} 0,315 \% \\
1: 10(\mathrm{w} / \mathrm{v}) 30^{\mathrm{I}} \\
\text { suhu } 20-25^{0} \mathrm{C}\end{array}$ & - & $\begin{array}{l}\text { Etanol } 96 \% \\
1: 10(\mathrm{~b} / \mathrm{v}) \\
\text { aquades } \\
\text { panas:aseton } \\
=1: 1\end{array}$ & - \\
\hline Identifikasi & $\begin{array}{l}\text { FTIR sebagai } \\
\text { kitin }\end{array}$ & $\begin{array}{l}\text { FTIR sebagai } \\
\text { kitin }\end{array}$ & $\begin{array}{l}\text { FTIR } \\
\text { sebagai kitin }\end{array}$ & $\begin{array}{l}\text { FTIR } \\
\text { sebagai kitin }\end{array}$ & $\begin{array}{l}\text { FTIR sebagai } \\
\text { kitin }\end{array}$ \\
\hline Deasetilasi & $\begin{array}{l}\mathrm{NaOH} 60 \%, \\
20: 1(\mathrm{v} / \mathrm{b}) \\
100-140^{\circ} \mathrm{C}, \\
1 \text { jam, } \\
\text { keringkan } 80^{0} \\
\mathrm{C} \text { waktu } 24 \\
\text { jam }\end{array}$ & $\begin{array}{l}\mathrm{NaOH} 50 \% \\
\mathrm{Suhu} 100- \\
150^{\circ} \mathrm{C} \text { waktu } 6 \\
\text { jam }\end{array}$ & $\begin{array}{l}\mathrm{NaOH} 50 \%, \\
\text { suhu } 100^{\circ} \mathrm{C}, \\
500 \mathrm{rpm}, \\
1: 15 \text {, waktu } \\
45 \text { menit }\end{array}$ & $\begin{array}{l}4 \text { gr kitin+ } 80 \\
\mathrm{~mL} \mathrm{NaOH} \\
70 \% \text { suhu } \\
100^{\circ} \mathrm{C} \text { waktu } \\
9,16,24 \text { jam }\end{array}$ & $\begin{array}{l}+\mathrm{NaOH} 50 \% \\
1: 20 \text { (b/v) } 70- \\
100^{\circ} \mathrm{C} \text { waktu } \\
30-120^{\mathrm{I}}, 70- \\
80^{\circ} \mathrm{C} 24 \mathrm{jam}\end{array}$ \\
\hline Hasil & $\begin{array}{l}\text { Hasil kitosan } \\
\text { DD 74,78\% }\end{array}$ & $\begin{array}{c}\text { Hasil kitosan } \\
\text { DD } 65,47 \%\end{array}$ & $\begin{array}{l}\text { Hasil kitosan } \\
\text { DD 52,58\% }\end{array}$ & $\begin{array}{l}\text { Hasil kitosan } \\
\text { DD 87,96\% }\end{array}$ & $\begin{array}{l}\text { Hasil kitosan } \\
\text { DD 79,65\% }\end{array}$ \\
\hline Penggunaan & $\begin{array}{l}\text { Isolasi } \\
\text { Kitosan } \\
\text { sebagai } \\
\text { adsorben } \\
\text { logam berat }\end{array}$ & $\begin{array}{l}\text { Adsorben zat } \\
\text { warna biru } \\
\text { metilena }\end{array}$ & $\begin{array}{l}\text { Adsorpsi } \\
\text { logam nikel }\end{array}$ & $\begin{array}{l}\text { Isolasi } \\
\text { Kitosan } \\
\text { sebagai } \\
\text { adsorben } \\
\text { logam berat }\end{array}$ & $\begin{array}{l}\text { Adsorben ion } \\
\text { logam } \\
\text { merkuri }\end{array}$ \\
\hline
\end{tabular}

\subsection{Karakterisasi kitosan}

Karakterisasi kitosan meliputi penentuan derajat deasetilasi, kadar air, rendeman, kelarutan (Kyoon No et al., 2000), pH dan viskositas. Spektrum infra merah digunakan untuk penentuan derajat deasetilasi kitosan yang terbentuk.

Frekuensi yang digunakan berkisar antara 4000 $\mathrm{cm}$-1 sampai dengan $400 \mathrm{~cm}-1$. Derajat deasetilasi kitosan ditentukan dengan metode base line yang ditentukan Domszy dan Robert serta Baxter (Khan et al., 2002).

Kitosan yang diperoleh dianalisis dengan FTIR untuk mengetahui Derajat Deasetilasi (DD), dengan metode garis oleh Moore dan Robert, 
Jurnal Biosains Pascasarjana Vol. 18 (2016) pp

(C) (2016) Sekolah Pascasarjana Universitas Airlangga, Indonesia

seperti ditunjukkan dalam persamaan. Sampel ditambahkan $\mathrm{KBr}$, dibuat pellet dan kemudian

$$
\% \mathrm{DD}=1-\left[\left(\frac{\mathrm{A}_{1655}}{\mathrm{~A}_{3450}}\right) \times \frac{1}{1,33}\right] \times 100 \%
$$

ditentukan spektrumnya (Hanafi, dkk, 1999), kemudian derajat deasetilasi dapat dihitung dengan metode baseline dengan cara:

Keterangan :

A1655 = nilai serapan pada $1655 \mathrm{~cm}-1$

A3450 = nilai serapan pada $3450 \mathrm{~cm}-1$

Tabel 4. Standar mutu kitosan (Suhartono, 2006)

$$
\begin{aligned}
& 1,33 \text { = perbandingan A1655 dengan A3450 } \\
& \text { pada derajat deasetilasi 100\% }
\end{aligned}
$$

Penetapan derajat deasetilasi kitosan ditentukan dari persentase banyaknya gugus asetil yang hilang dan berubah menjadi gugus amina. Hasil proses deasetilasi senyawa kitin adalah senyawa kitosan yang memiliki sifat dapat larut dalam asam asetat encer. Derajat deasetilasi ditentukan dengan menghitung serapan pada panjang gelombang $1655 \mathrm{~cm}-1$ dan $3450 \mathrm{~cm}-1$.

Dalam formulasi sediaan farmasetik, kitosan harus memiliki persyaratan seperti berwarna putih atau kekuningan,bentuk bubuk, $\mathrm{pH}$ 6,5-7,5, derajat deasetilasi $70-100 \%$, Kadar air $\leq 10 \%$, Kadar abu $\leq 2 \%$ Kadar nitrogen $\leq 5 \%$, tidak berasa, dan tidak berbau (Protan Labortories. 1987).

\begin{tabular}{lll}
\multicolumn{1}{c}{ Parameter } & \multicolumn{1}{c}{ Daewoo Korea } & \multicolumn{1}{c}{ Lab. Protan Jepang } \\
\hline Penampakan & Bubuk putih atau kuning & Bubuk kuning \\
Ukuran partikel & $25-200$ mesh & Serpihan sampai serbuk \\
Kadar air & $\leq 10 \%$ & $\leq 10 \%$ \\
Kadar abu & $\leq 0,5 \%$ & $\leq 2 \%$ \\
Kadar protein & $\leq 0,3 \%$ & - \\
Derajat deasetilasi (DD) & $\geq 70 \%$ & $\geq 70 \%$ \\
Viskositas & $50-500 \mathrm{cps}$ & $200-2000 \mathrm{cps}$ \\
Ketidaklarutan & $<1 \%$ & - \\
Kadar logam berat. As. Pb & $<10$ ppm & - \\
pH & $7-9$ & $7-8$ \\
Bau & Tidak berbau & Tidak berbau \\
\hline
\end{tabular}


Jurnal Biosains Pascasarjana Vol. 18 (2016) pp

(C) (2016) Sekolah Pascasarjana Universitas Airlangga, Indonesia

Tabel 5. Aplikasi kitosan berdasarkan derajat deasetilasi dan berat molekul (Suhartono, 2006)

\begin{tabular}{|c|c|c|c|c|}
\hline No. & $\begin{array}{l}\text { Derajat } \\
\text { Destilasi (\%) }\end{array}$ & $\begin{array}{l}\text { Berat Molekul } \\
\qquad(\mathrm{kDa})\end{array}$ & Aplikasi & Referensi \\
\hline 1. & 85 & - & $\begin{array}{l}\text { Pengikat kation } \mathrm{Co}, \mathrm{Ni}, \mathrm{Ag} \text {, } \\
\mathrm{Zn}\end{array}$ & $\begin{array}{l}\text { Lima IS \& C. Airoldi, } \\
2004\end{array}$ \\
\hline 2. & 90 & 390 & Transfeksi gen & Kiang T et al., 2004 \\
\hline 3. & 85 & - & Wound-healing dressing & Min BM et al., 2004 \\
\hline 4. & 80 & - & Antikanker & $\begin{array}{l}\text { Dhiman HK et al., } \\
2004\end{array}$ \\
\hline 5. & 90 & - & Antioksidan & Je JY et al., 2004 \\
\hline 6. & 75 & 150 & Antitumor, drug delivery & $\begin{array}{l}\text { Sakkinen M et al., } \\
2003\end{array}$ \\
\hline 7. & 58 & 5 & Antitumor & Qin C et al., 2002 \\
\hline 8. & 92 & 87 & Antimikroba & Juma M et al., 2002 \\
\hline 9. & 89 & - & $\begin{array}{l}\text { Stimulator proliferasi } \\
\text { fibroblast kulit manusia }\end{array}$ & $\begin{array}{l}\text { Howling GI et al., } \\
2001\end{array}$ \\
\hline
\end{tabular}

Karakteristik lain dari kitosan yaitu penentuan kadar air. Kadar air dihitung dengan mengukur pengurangan berat sampel sebelum dan setelah pemanasan. Sejumlah sampel dikeringkan dalam oven pada suhu $1050 \mathrm{C}$ selama 3 jam, kemudian dikeringkan dalam eksikator ( Suhartono, 2006 ) Selain itu penentuan rendemen kitosan dihitung berdasarkan perbandingan berat kitosan dengan berat sampel limbah cangkang menggunakan rumus:

$$
\begin{gathered}
\text { Rendemen }=(\text { Berat kitosan/Berat Limbah } \\
\text { cangkang }) \times 100 \%
\end{gathered}
$$

Karakterisasi kitosan yang lain adalah kelarutan menurut (No et al., 2000). Kitosan sebanyak $0,5 \%(\mathrm{~b} / \mathrm{v})$ dilarutkan dalam asam asetat $1 \%$ (v/v), lalu difiltrasi. Persentase kelarutan kitosan ditunjukkan dengan kitosan yang tersisa dibandingkan dengan kitosan awal .

Viskositas kitosan (Hwang et al., 1997) diukur menggunakan Ubbelohde dilution viscometer yang dicuci dengan akuades dan dikeringkan terlebih dahulu. Larutan kitosan dibuat dalam berbagai konsentrasi dalam pelarut asam asetat aqueous $0,1 \mathrm{M}$ dan sodium asetat 0,25 $\mathrm{M}$. Masing-masing sampel ditempatkan di dalam viskometer sebanyak $10 \mathrm{ml}$. Sampel diambil hingga ke labu di bagian atas viskometer secara perlahan. Waktu yang dibutuhkan sampel untuk mengalir antara dua batas yang mengapit labu tersebut dicatat. Sebagai blanko, digunakan pelarut asam asetat aqueous $0,1 \mathrm{M}$ dan sodium asetat 0,25 $\mathrm{M}$ dan ditentukan viskositasnya dengan cara yang sama. Viskositas spesifik dihitung dengan cara berikut:

$$
\eta_{s p}^{\prime}=\frac{t-t_{0}}{t_{0}}
$$

Keterangan:

ทेsp = viskositas spesifik (detik)

$\mathrm{t} \quad=$ waktu yang diperlukan untuk mengalirnya larutan sampel (detik)

$\mathrm{t}_{0} \quad=$ waktu yang diperlukan untuk mengalirnya larutan solven (detik) 
Melalui cara ini akan diperoleh nilai viskositas spesifik, yang tidak mempunyai satuan.

\section{METODE PENELITIAN}

Pada penelitian ini dilakukan isolasi kitosan dari cangkang rajungan (Portunus pelagis) yang diambil di Pantai Kenjeran . Pengolahan cangkang menjadi kitosan dilakukan melalui beberapa tahap yaitu:

\subsection{Isolasi kitosan}

Isolasi Kitosan dari cangkang rajungan dengan mencuci cangkang dibawah air mengalir hingga bersih disikat serta dihilangkan kotoran ditiriskan, dijemur dibawah matahari, lalu digiling hingga halus menjadi serbuk, diayak dengan ukuran 100 Mesh.

\subsection{Deproteinasi}

Bahan ditimbang, ditambahkan $\mathrm{NaOH} 3 \%$ 1:6 (w/v) dipanaskan selama 30 menit pada $85{ }^{\circ} \mathrm{C}$ dinetralkan dengan air suling hingga $\mathrm{pH} 7$ lalu disaring dengan penyaring Büchner, di oven $35^{\circ} \mathrm{C}$ selama 24 jam (Sinardi, 2013). Hasil berupa padatan bebas dari protein.

\subsection{Demineralisasi}

Tabel 6. Hasil penimbangan sampel cangkang hingga penimbangan tahapan hasil deasetilasi

\begin{tabular}{|c|c|c|c|c|c|c|}
\hline Sampel & $\begin{array}{c}\text { Penimbanga } \\
\text { n awal } \\
\text { (g) }\end{array}$ & $\begin{array}{c}\text { Hasil proses } \\
\text { Deprotenasi }(\mathrm{g})\end{array}$ & $\begin{array}{c}\text { Hasil } \\
\text { proses } \\
\text { Deminer } \\
\text { alisasi } \\
\text { (g) }\end{array}$ & $\begin{array}{c}\text { Demineralisasi } \\
\text { ke - II (g) }\end{array}$ & $\begin{array}{c}\text { Penamba } \\
\text { han } \\
\mathrm{H}_{2} \mathrm{O}_{2}(\mathrm{~g})\end{array}$ & $\begin{array}{c}\text { Isolat Hasil } \\
\text { Deasetilasi } \\
\text { (g) }\end{array}$ \\
\hline $\mathrm{Rj}_{1}$ & 100,5960 & 90,4107 & 30,1311 & & 16,6975 & 13,1337 \\
\hline $\mathrm{Rj}_{2}$ & 100,3363 & 90,3607 & 25,0302 & 19,0203 & 16,0056 & 11,4947 \\
\hline $\mathrm{Rj}_{3}$ & 100,2473 & 89,3561 & 30,1102 & 23,1102 & 15,5273 & 15,3434 \\
\hline Rerata \pm SD & $100 \pm 0.18118$ & $90 \pm 0.594965$ & $28 \pm 2.93899$ & & $16 \pm 0.58834$ & $13 \pm 1.931389$ \\
\hline
\end{tabular}

Keterangan:

$\mathrm{Rj} 1$ : cangkang rajungan ulangan ke-1

$\mathrm{Rj} 2$ : cangkang rajungan ulangan ke-2

$\mathrm{Rj} 3$ : cangkang rajungan ulangan ke-3

\subsection{Spektrum FTIR Standar baku kitin dari BPPT}

Spektrum FTIR standar baku kitin yang berasal dari BPPT, garis vertikal menunjukkan persentase transmitans dan garis horizontal menunjukkan bilangan gelombang. Karakterisasi kitin pada serapan FTIR kitin standar terlihat pita serapan gugus $\mathrm{OH}$ ditunjukkan pada puncak 3458,43, pita serapan C-H ulur terlihat pada
Sampel ditambahkan $\mathrm{HCl} 1 \mathrm{~N}$ dengan perbandingan 1:10, diaduk pada suhu $75^{\circ} \mathrm{C}$ dengan waktu 1 jam dinetralkan hingga $\mathrm{pH}$ netral $\mathrm{pH} 7$ dan disaring dipanaskan $35^{\circ} \mathrm{C}$ selama 24 jam. Hasil isolasi berupa kitin (Sinardi, 2013). Pada proses ini dilakukan pengulangan sebanyak 2 kali untuk menghilangkan $\mathrm{CaCO} 3$ yang masih tersisa. 3.4 Deasetilasi

Sampel ditambahkan $\mathrm{NaOH} 45 \%$ 1:20 (b/v) dipanaskan suhu $110^{\circ} \mathrm{C}$ dalam waktu $1 \mathrm{jam}$, lalu dinetralkan hingga $\mathrm{pH} 7$ disaring lalu di oven suhu $80^{\circ} \mathrm{C}$ selama 24 jam. Hasilnya berupa kitosan (Yen et al., 2009 ).

\subsection{Identifikasi dengan FTIR (Fourier}

Transform Infra Red)

Membuktikan terbentuknya kitin dan kitosan, hasil isolasi dianalisa dengan dibuat pellet dengan $\mathrm{KBr}$ dan selanjutnya diamati spektrum IR nya dengan FTIR .

\section{HASIL DAN PEMBAHASAN}

Hasil penimbangan sampel cangkang awal hingga tahapan hasil deasetilasi penelitian ini selengkapnya disajikan pada Tabel 6 . 
Jurnal Biosains Pascasarjana Vol. 18 (2016) pp

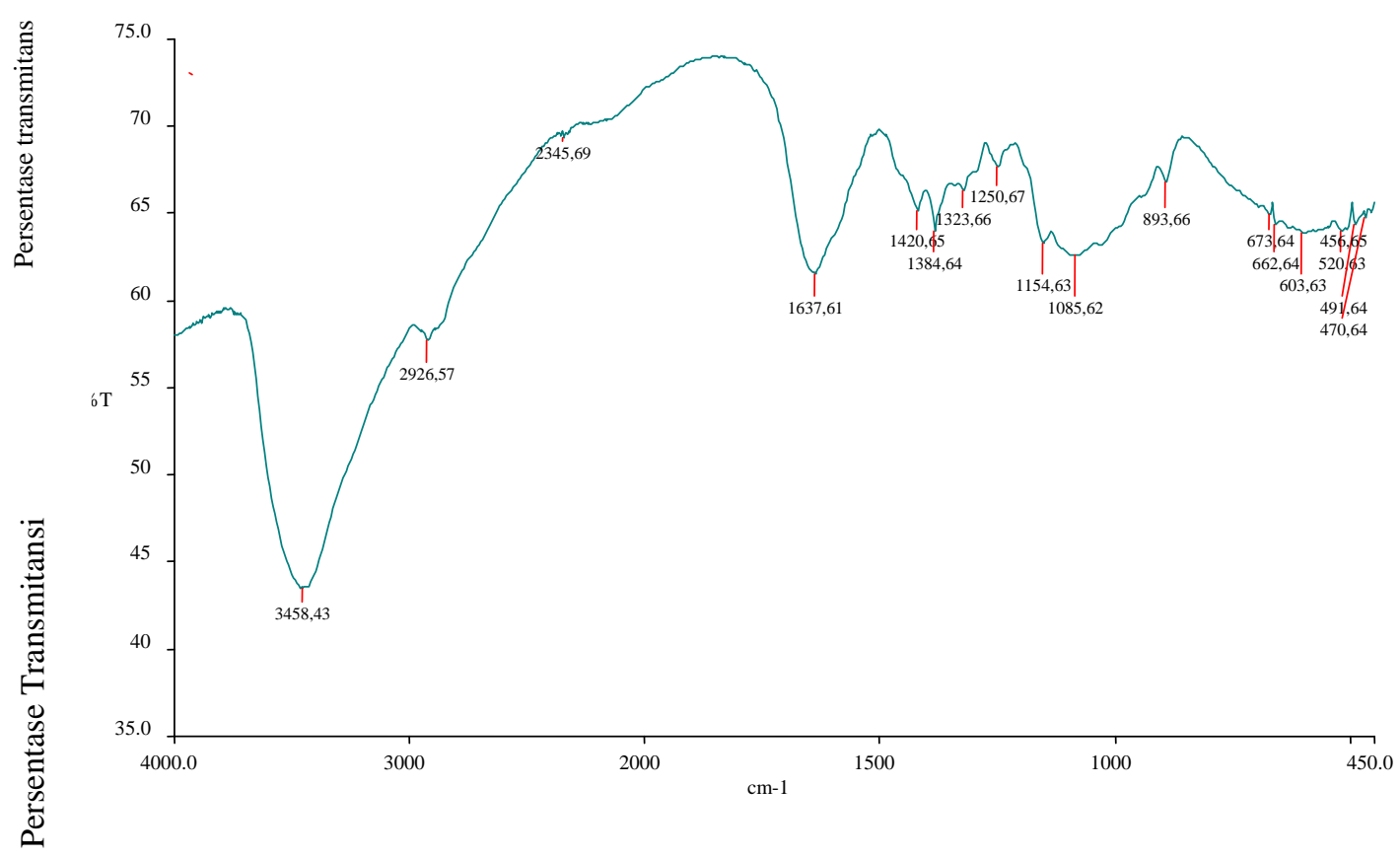

Gambar 4. Spektrum FTIR standar baku kitin dari BPPT

\subsection{Spektrum FTIR kitin Cangkang Rajungan}

Hasil dari spektrum FTIR kitin sampel rajungan pada garis vertikal menunjukkan persentase transmitans dan garis horizontal menunjukkan bilangan gelombang. Pada gambar 5 serapan FTIR untuk kitin hasil isolasi dari rajungan menunjukkan adanya pita serapan gugus
OH ditunjukkan pada puncak 3468,45, pita serapan C-H ulur terlihat pada puncak 2928,58 pita serapan $\mathrm{C}=\mathrm{O}$ ulur terlihat pada puncak 1639,63 , pita serapan C-O-C terlihat pada puncak 1075,69 dan pita serapan N-H kibasan terlihat pada puncak 616,71

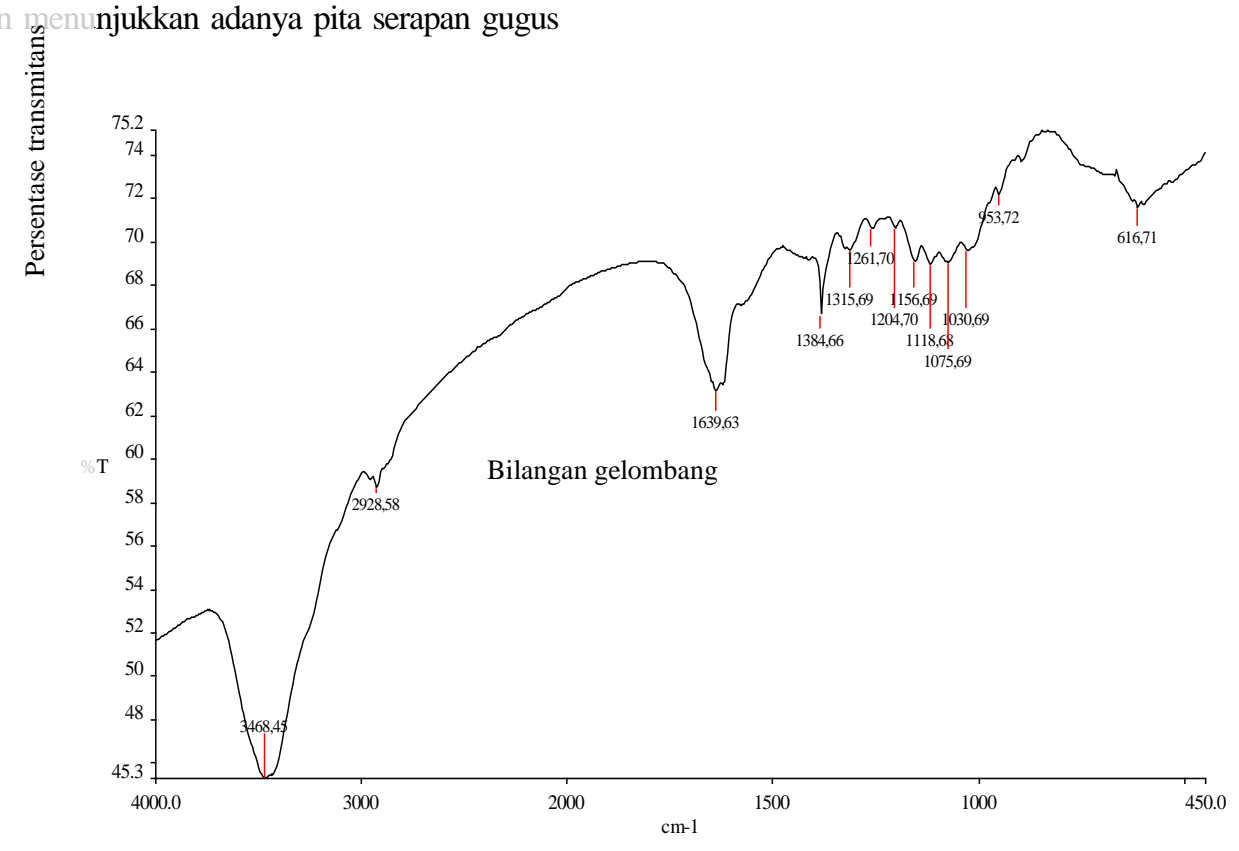


Jurnal Biosains Pascasarjana Vol. 18 (2016) pp

(C) (2016) Sekolah Pascasarjana Universitas Airlangga, Indonesia

Gambar 5. Spektrum FTIR kitin dari bahan baku cangkang Rajungan

4.3 Spektrum FTIR Standar baku kitosan dari BPPT

Spektrum FTIR standar kitosan yang berasal dari BPPT pada garis vertikal menunjukkan persentase transmitans dan garis horizontal menunjukkan bilangan gelombang. Pada gambar 6 menunjukkan serapan FTIR kitosan standard dari BPPT terlihat pita serapan gugus $\mathrm{N}-\mathrm{H}$ amida ditunjukkan pada puncak 3435,54 pita serapan C-N terlihat pada puncak 2339,78 pita serapan N-H amina 1654,67 dan pita serapan C-O alkohol 1076,64 .

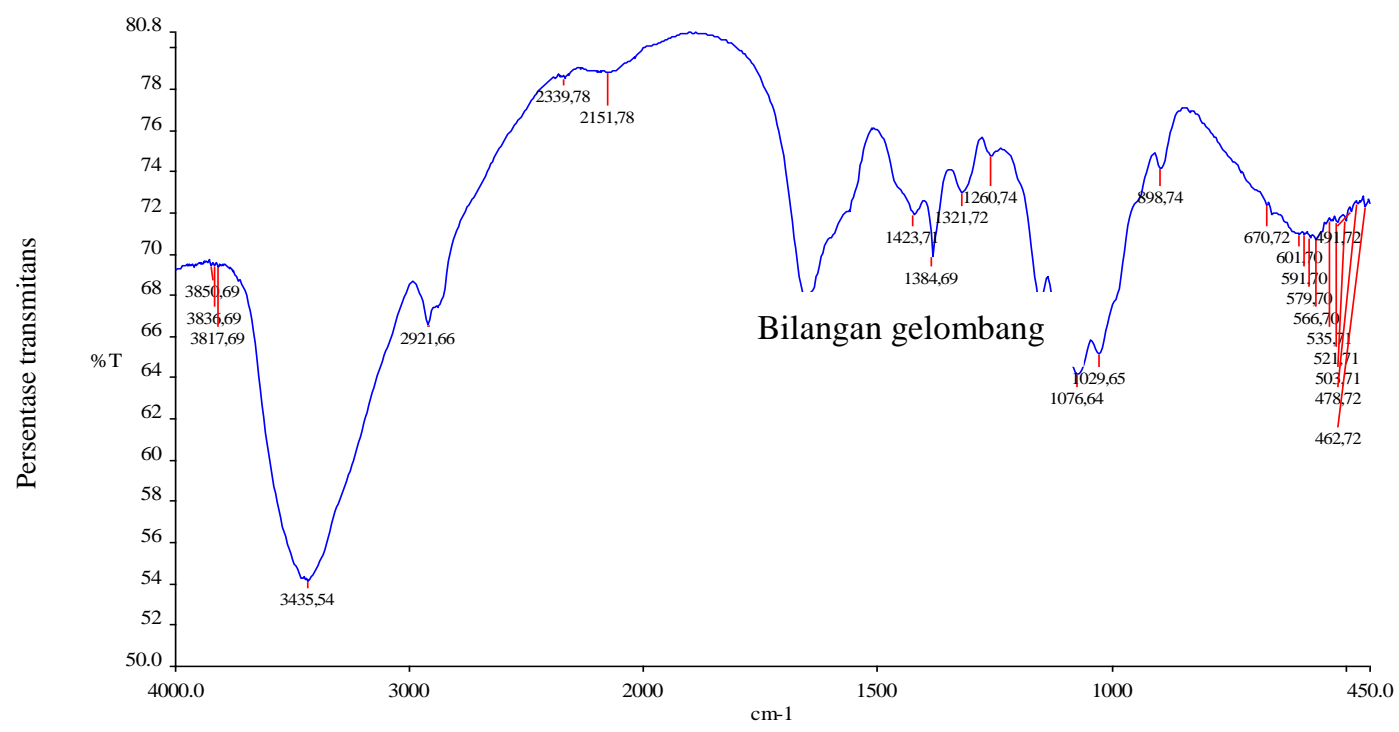

Bilangan gelombang

Gambar 6. Spektrum FTIR Standar baku kitosan dari BPPT

\subsection{Spektrum FTIR Standar baku kitosan dari bahan baku cangkang Rajungan}

Spektrum FTIR kitosan yang berasal dari bahan baku rajungan pada garis vertikal menunjukkan persentase transmitans dan garis horizontal menunjukkan bilangan gelombang. Pada gambar 7 menunjukkan karakterisasi serapan FTIR untuk kitosan hasil isolasi dari cangkang rajungan terlihat pita serapan gugus N-H amida ditunjukkan pada puncak 3435,54 pita serapan C-N terlihat pada puncak 2339,78 pita serapan N-H amina 1654,67 dan pita serapan C-O alkohol 1076,64 seperti diperlihatkan pada Gambar 7.

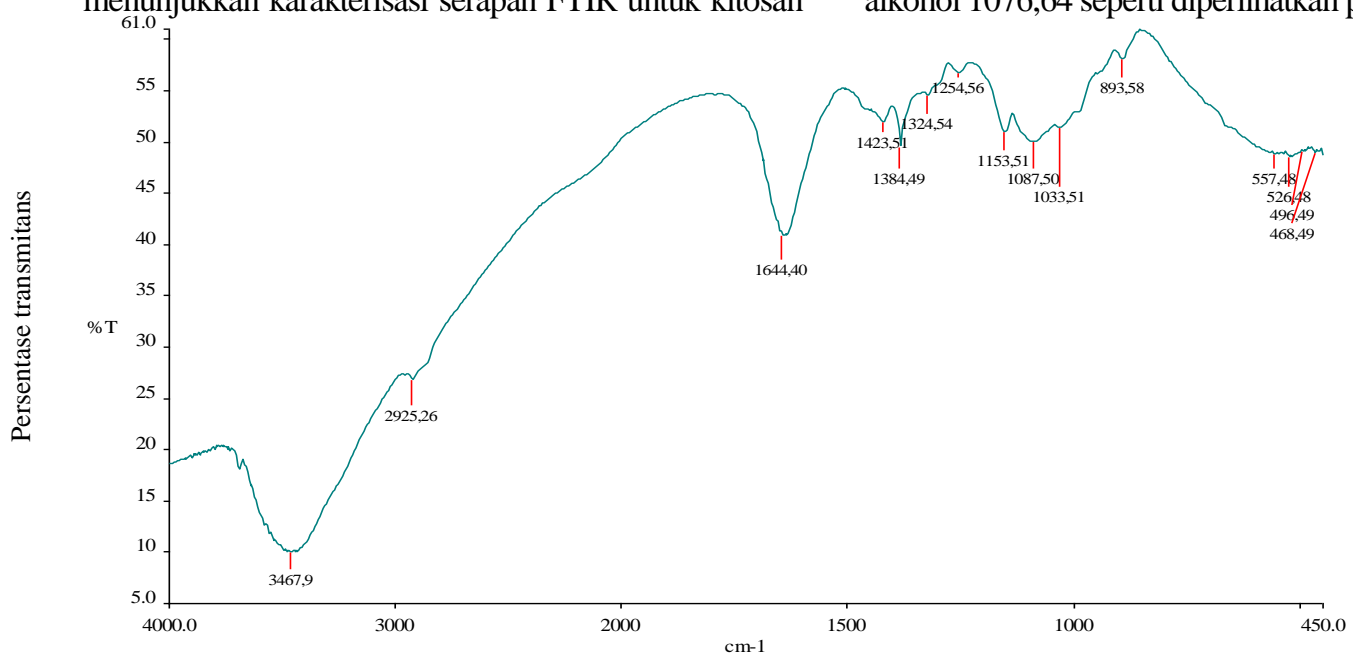

JBP Vol. 18, No. 2, Agustus 2016-i Bilangan gelombang 
Gambar 7. Spektrum FTIR kitosan bahan baku cangkang Rajungan

Pada identifikasi hasil ekstraksi kitosan, spektrum FTIR sudah dapat dikatakan identik bila dibandingkan dengan kitosan komersial menurut sarbon et al., 2014 dan senyawa baku dari BPPT. Kitosan komersial menurut Sarbon et al., 2014 terdapat pita serapan dari N-H amida pada bilangan gelombang 3369,11-3413,07 juga terdapat pada baku pada BPPT dengan nilai 3435,54 sedangkan pada cangkang rajungan terdapat pada 3467,9 .

Pita serapan C-O alkohol kitosan komersial menurut Sarbon et al., 2014 pada rentang 1128,211129,02 pada baku BPPT bernilai 1076,64, dan kitosan dari rajungan 1087,50. Pada kitosan hasil ekstraksi Sarbon, et al., 2014 pita NH amina didapatkan pada 1622,76-1623,92 cm-1 terlihat pula pada baku BPPT dengan nilai 1654,67, sedangkan pada kitosan dari rajungan ditunjukkan pada 1644,40 . Hal ini menunjukkan adanya pita serapan spesifik N-H (bending) pada rentang 1640-1550 cm-1 yang sesuai dengan Pavia et al., 2009.

Pada spektra FTIR diatas menunjukkan bahwa FTIR kitosan yang diisolasi dari rajungan memenuhi kesesuaian spektra sampel dengan baku khususnya pada bilangan gelombang di daerah sidik jari (1500-500). Proses deasetilasi merupakan proses pembentukan kitosan dari kitin menggunakan $\mathrm{NaOH}$ untuk mengganti gugus asetamida dengan gugus amino. Pada penggunaan $\mathrm{NaOH}$ dengan konsentrasi dibawah $40 \%$ dan suhu dibawah $100^{\circ} \mathrm{C}$ serta pengadukan yang tidak homogen akan mengakibatkan terbentuknya cairan dengan viskositas yang tinggi (Tsaih, 2003). Hal ini akan mengakibatkan rusaknya sampel yang diisolasi untuk itu diperlukan penggunaan $\mathrm{NaOH}$ diatas $40 \%$ dan suhu $110^{\circ} \mathrm{C}$ serta pengadukan yang homogen untuk mendapatkan kitosan yang terbaik dengan viskositas yang stabil sehingga cairan tidak rusak dan mengental. Semakin tinggi konsentrasi $\mathrm{NaOH}$, derajad deasetilasi (DD) semakin besar, namun hal ini tidak selalu memberikan kenaikan DD yang signifikan (Tsaih and Chen, 2002).

\section{KESIMPULAN DAN SARAN}

Hasil penelitian menunjukkan kitin dan kitosan dapat diekstraksi dari cangkang Rajungan yang mana bahan tersebut merupakan limbah yang mencemari lingkungan dan memiliki nilai ekonomi rendah.

\section{UCAPAN TERIMA KASIH}

Terima kasih penulis sampaikan kepada Pimpinan Sekolah Pasca Sarjana, terima kasih juga penulis ucapkan kepada Staf Laboratorium Analisis Fakultas Farmasi atas bantuan penggunaan alat dan bahan, dan teman-teman seperjuangan.

\section{DAFTAR PUSTAKA}

Ali, Moftah, Ani Mulyasuryani, and Akhmad Sabarudin. 2013. Adsorption of Cadmium By Silica Chitosan. The Journal of Pure and Applied Chemistry Research, 2 (2) : 62-66.

Albeson., Danny., Nybakken, J.W. 1986. Biologi Laut. Suatu Pendekatan Ekologis. Gramedia. Jakarta.

Bachok, Z., P. L. Mfilinge \& M. Tsuchiya. 2006. Food Sources of Coexisting Suspension-Feeding Bivalves as Indicated by Fatty Acid Biomarkers, Subjected to the Bivalves Abundance on a Tidal Flat. Journal of Sustainability Science and Management. $1: 92-111$.

Cheman, Y.B., Rohman, A. 2012. Analysis of canola oil in virgin coconut oil using FTIR spectroscopy and chemometrics. J Food Pharm.Sci (2013), 59

Dance, S.P., Abbott Cecilia. 2000. Compendium of Seashells. Odyssey. Rolling Hills, USA.

Darmono. 2001. Lingkungan Hidup dan Pencemaran : Hubungannya dengan Toksikologl senyawa Logam.Universitas Indonesia. UI•Press.jakana.

Darjito, D., Purwonugroho, D., \& Ningsih, R., 2014, The Adsorption of $\mathrm{Cr}$ (VI) Using Chitosan-Alumina Adsorbent. The Journal of Pure and Applied Chemistry Research, 3 (2)

Debenay, J. P. \& D. L. Tack. 1994. Environmental conditions, growth and production of Anadara senilis (Linnaeus, 1758) in a Senegal Lagoon. Journal Mollusca Study. 60 : 113-121.

Departemen Kelautan dan Perikanan. 2000. Statistik Data Perikanan. Jakarta:

Departemen Kelautan dan Perikanan.

Fernandez-Kim, S.-O., 2004, Physicochemical and Functional Properties of Crawfish Chitosan as Affected by Different Processing Protocols, A Thesis in Department of Food Science, Seoul National University. 
Jurnal Biosains Pascasarjana Vol. 18 (2016) pp

(C) (2016) Sekolah Pascasarjana Universitas Airlangga, Indonesia

Hanafi, M., Syahrul A., Efrina D., dan B. Suwandi,, 1999. Pemanfaatan Kulit Udang untuk Pembuatan Kitosan dan Glukosamin, LIPI Kawasan PUSPITEK, Serpong.

Hardjito, L. 2006. Chitosan Sebagai Bahan Pengawet Pengganti Formalin. Majalah Pangan. Media Komunikasi dan Informasi.

Hargono dan M. Djaeni, Pemanfaatan Kitosan dari Kulit Udang sebagai Pelarut Lemak. Prosiding Seminar Nasional Teknik Kimia Indonesia.

Huang, K. S., Jeng-Shian Cheng.,Fun-Eu Lin.\& ShyhJer Lin. 2009. Preparation

and Properties of PAA-Chitosan/SiO2 Hybrid Materials. Kun Shan University Taiwan. 1-20

Hien, V. D., D. Q. Huong, dan P. T. N. Bich. 2010. Study of the Formation of Porous Hydroxyapatite Ceramics from Corals via Hydrothermal Process. Journal of Chemistry. Vol. 48 (5). P. 591 - 596.

Honarkar, H. and Barikani, M., (2009), Applications of biopolymers I: chitosan, Published online: SpringerVerlag.

Hutahaean,I.S. 2001. Penggunaan Kitosan Sebagai Penyerap Logam Zinkum(Zn2+) Dan Logan Kromium $(\mathrm{Cr} 3+)$ dengan Metode Spektrofotometri Serapan atom. Skripsi. Medan: Jurusan Kimia FMIPA USU

Hwang J, Hong S, Kim C. 1997. Effect of molecular weight and $\mathrm{NaCl}$ concentration on dilute solution properties of chitosan. J Food Sci Nutr 2:1-5.

Khan TA, Kok K, Hung S. 2002. Reporting degree of deacetylation values of

chitosan: the influence of analytical methods. J Pharm Pharmaceut Sci

5:205-212.

Guillen, M.D. dan Cabo, N., 1997, Infrared Spectroscopy in the Study of Edible Oils and Fats, J. Sci. Food Agri.,75:1-11.

Juwana, S. dan Kasijan Romimohtarto, 2000, Rajungan Perikanan, Cara Budidaya dan Menu Masakan. Djambatan, Jakarta.

Khan T.A., K.K. Peh, S.C. Hung. 2002. Reporting degree of deacetylation values of chitosan: the influence analytical methods. Journal of Pharmacological Science 5 (3): 205-212.

Knorr D. 1982. Function properties of chitin and chitosan. J Food Sci 47(36).

Kobayashi C.C, De Fernandes, K.C. Miranda, De Sonsa, and Silva Mdo R. 2004.
Candiduria in Hospital Patients: A Study Prospective Mycopathologia 158(1):49-52

Kumar, Ravi, N., V., Majeti. 2000. A review of chitin and chitosan applications. Reactive \& Functional Polymers 46, 1-27.

Kurita, K. 2001. Controlled functionalization of the polysaccharide chitin. Journal of Polimer Science. 26, 1921-71.

Kubota, N., Tastumoto, N., Sano, T. \& Toya, K. (2000). A simple preparation of half Nacetylated chitosan highly soluble in water and aqueous organic solvents. Carbohydrate Research, Vol. 324, pp. 268-274.

Kurniasih, D., Atikah, A., \& Sulistyarti, H., 2012, The Coated-Wire Ion Selective Electrode (CWISE) of Chromate Using PVC-Membrane Based on Chitosan as A Carrier, The Journal of Pure and Applied Chemistry Research, 1 (1) : 33-40.

Kusriningrum, R. S. 2008. Perancangan Percobaan. Universitas Airlangga. Surabaya. hal. 43-63.

Kyoon No, Meyers SP. 1997. Preparation of Chitin and Chitosan. Di dalam:

Muzzarelli RAA, Peter MG (eds.). Chitin Handbook. European Chitin Society. Italy.

Mali, S., M.V.E. Grossmann, M.A. Garcia, M.N. Martino, and N.E. Zaritzky. 2005. Microstructural characterization of yam starch films. J. Carbohydrate Polymer 50: 379-386.

Matheis F. J. D. P. Tanasale, Amos Killay, dan Marsela S. Laratmase, 2011, Kitosandari Limbah Kulit Kepiting Rajungan (Portunus sanginolentus L.) sebagaiAdsorben Zat Warna Biru Metilena, Jurnal Natur Indonesia, 14 (2) : 165-171.

Mekawati, Fachriyah, E. dan Sumardjo, D., (2000), Aplikasi Kitosan Hasil tranformasi Kitin Limbah Udang (Penaeus merguiensis) untuk Adsorpsi Ion Logam Timbal, Jurnal Sains and Matematika, FMIPA Undip, Semarang, Vol. 8 (2), hal. 51- 54

Moosa, M.K., I. Aswandi dan A. Kasry.1985. Kepiting bakau, Scylla serrata (Forskal) dari perairan Indonesia. LON-LIPI, Jakarta.

Muzzarelli RAA, Rochetti R, Stanic V, Weckx M. 1997. Methods for the

determination of the degree of acetylation of chitin and chitosan. Di dalam: Muzzarelli RAA, Peter MG (eds.). Chitin Handbook. Grottamare:

European Chitin Soc.

No, H.K. Lee, S.H, Park, N.Y dan Meyers, S.P.2003. Comparison Of Phsycochemical Binding And 
Antibacterial Properties Of Chitosans prepared Without And With Deprotei Ization process. Journal of agriculture and food chemistry 51: 7659-7663

Nontji. A. 2007. Laut Nusantara. Penerbit Djambatan : Jakarta

Nurdin, J., N. Marusin, Izmiarti, A. Asmara, R. Deswandi dan J. Marzuki. 2006. Kepadatan populasi dan pertumbuhan kerang darah Anadara antiquate L. (Bivalvia: Arcidae) di Teluk Sungai Pisang, Kota Padang, Sumatra Barat. Makara Sains, 10(2). 96-101.

Prianto, E. 2007. Peran Kepiting sebagai Spesies Kunci (Keystone Spesies) pada Ekosistem Mangrove. Prosiding Forum Perairan Umum Indonesia IV. Balai Riset Perikanan Perairan Umum. Banyuasin

Protan Labortories. 1987. Catioal Polymer for Recovering Valuabe by Products from Processing Waste Burgges. USA

Peniston, Q.P. and Johnson, E., 1980, Process for the Manufacture of Chitosan, US Patent 4.195.175

Rahayu, L. H., dan Purnavita, S., (2007), Optimasi Proses Deproteinasi dan Demineralisasi pada Isolasi Kitin dari Limbah Cangkang Rajungan (Portunus pelagicus), Prosiding: Teori Aplikasi Teknologi Kelautan, ITS Surabaya, hal. III.8 III.11.

Rakhmawati, E., (2007), Pemanfaatan Kitosan Hasil Deasetilasi Kitin Cangkang Bekicot Sebagai Adsorban Zat Pewarna Remazol Yellow, Surakarta ,Universitas Sebelas Maret.

Rahmadani. 2011. Pemanfaatan kitoan dari limbah cangkang bekicot sebagai adsorben logam tembaga..Medan.Universitas Negeri Medan

Reid, L. M., O‘Donnell, C. P., dan Downey, G., 2006, Recent technological advances for the determination of food authenticity, Trends Food Sci. Technol., 17:344-353

Rinaudo, marguerite. 2006. Chitin and Chitosan. Properties and applications. Progress in polymer science.Elsevier 31, 603-632

Rismiarti, Z., Atikah, A., \& Sulistyarti, H., 2013, Construction and Characterization of Coated Wire Oxalate Ion Selective Electrode Based on Chitosan, The Journal of Pure and Applied Chemistry Research, 3 (1) : 19-26

Rochima E. 2005. Aplikasi kitin deasetilase termostabil dari Bacillus papandayan
K29-14 asal Kawah Kamojang Jawa Barat pada pembuatan kitosan. Tesis. Bogor: Program Pascasarjana, IPB.

Robert. G. A.1992. Chitin Chemistry., Nottingham Politechnic, McMillan, USA.

Rohman, Cheman, Y. B., Ismail, A and Puziah, H. 2011. FTIR spectroscopy combined with cheometrics for analysis of cod liver oil in binary mixture with corn oil. International Food Research Journal. 18 : 736-740

Romimohtarto, K dan S. Juwana. 2007. Biologi Laut Ilmu Pengetahuan tentang Biota Laut. Djambatan. Jakarta.

Rumengan, I.F.M., Suryanto, E., Modaso, R., Wullur, S., Tallei, T.E. and Limbong, D. 2014. Structural Characteristics of Chitin abd Chitosan Isolated from the Biomass of Cultivated Rotifer, Brachionus rotundiformis. International Journal of Fisheries and Aquatic Sciences 3(1):12-18.

Sabarudin, A., and Motomizu, S., 2013, Functionalization of Chitosan with 3, 4, 5Trihydroxy Benzoic Acid Moiety for The Uptake of Chromium Species, The Journal of Pure and Applied Chemistry Research, 2 (1) : 48-54.

Sankararamakrishnan, N. \& Sanghi, R. (2006). Preparation and characterization of a novel xanthated chitosan. Carbohydrate Polymers, Vol. 66, pp. 160-167.

Sarbon, S. kamaruzaman. 2014. Chitosan extracted from mud crab (Scylla olivicea) shells : physicochemical and antioxidant properties. Food Sci Technol, 1-10, Springer Inc

Sasic, S., dan Ozaki, Y., 2010, Raman, Infrared, and Near-Infrared. Chemical Imaging, 67 - 73, John Wiley and Sons, Inc., Hoboken.

Shahidi F, Synowiecki J (1991) Isolation and characterization of nutrients

and value- added products from snow crab (Chionoecetes Opilio) and shrimp (Pandalus Borealis) processing discards. J Agric Food Chem 39(8):1527-1532

Shahidi, F. and Abuzaytoun, R., (2005), Chitin, Chitosan, And Co-Products: Chemistry, Production, Applications, And Health Effects, Advances In Food And Nutrition Research, Vol 49, Elsevier Inc.

Shimek, R.L. 2008. Crabs, (Online). Website : www.reefkeeping.com. Diakses pada tanggal 10 Maret 2012.

Sinardi. 2013. Pembuatan karakterisasi dan aplikasi kitosan dari cangkang kerang hijau (Mytulus 
Jurnal Biosains Pascasarjana Vol. 18 (2016) pp

(C) (2016) Sekolah Pascasarjana Universitas Airlangga, Indonesia

virdis Linneaus) sebagai koagulan penjernih air. Bandung. ITB

Srijanto, B., (2003), "Kajian Pengembangan Teknologi Proses Produksi Kitin dan Kitosan Secara Kimiawi”, Prosiding seminar Nasional Teknik Kimia Indonesia 2003, Volume I, hal. F01-1 F01-5.

Stuart, B., 2004, Infrared Spectroscopy: Fundamentals and Apllications, 19-20, 33-34, John Wiley \& Sons, Inc., New York.

Suhartono, M.T. 2006. Pemanfaatan Kitin, Kitosan, kitooligosakarida. Foodreview J (6) : 30-33

Triana. 2004. Synthesis of chitosan from chitin of escargot (Achatina fulica). Biofarmasi J (2) 6468

Wang H, Fang YE, Yan Y. 2001. Surface modification of chitosan membranes by alkane vapor plasma. J Mat Chem 11: 1374-7

Watson, S., Beydoun, D., Scott, J. \& Amal, R., 2004. Preparation of nanosized crystalline $\mathrm{TiO} 2$ particles at low temperature for photocatalysis, J. Nanopart. Res., Volume 6, pp.193-207.

Widwiastuti, H., Mulyasuryani, A., \& Sabarudin, A., 2013, Extraction of Pb2+ using Silica from Rice Husks Ash (RHA)-Chitosan as Solid Phase, The
Journal of Pure and Applied Chemistry Research, 2 (1) : 42-47. 10.

W. J. Nybakken, Biologi Laut Suatu Pendekatan Ekologis, PT. Gramedia, Jakarta, 1988

Yuliusman dan Adelina, P.W., 2010, Pemanfaatan Kitosan dari Cangkang Rajungan pada Proses Adsorpsi Logam Nikel dari Larutan NiSO4, Prosiding Seminar Rekayasa Kimia dan Proses 2010, ISSN : 1411-4216.

Yunizal dkk, (2001), Ekstraksi Khitosan dari Kepala Udang Putih (Penaeus merguensis). J. Agric. Vol. 21 (3), hal 113-117

Yen MT, Yang JH, Mau JL (2009) Physicochemical characterization of chitin and chitosan from crab shells. Carbohydr Polym 75:15-21

Zakaria, M. B. , M. J. Jais. , Wan-Yaacob Ahmad. , Mohd Rafidi Othman dan Z. A. Harahap., 2002. Penurunan Kekeruhan Efluen Industri Minyak Sawit (EIMS) Oleh Koagulan Konvensional Dan Kitosan. Prosiding Seminar Bersama UKM-ITB ke-5. Universitas Kebangsaan Malaysia. Malaysia.

Zeleny. M. 1982. Multiple Criteria Decision Making. Mc.Graw Hill. New York 